\title{
A TRILOGIA DE GIL VICENTE
}

\section{Dalla Pereira da Costa *}

Todo o artista como toda a época histórica, tem em si um número limitado de verdades que por si descobriu e a que deu forma, simbólica e vivida. Verdades, como pontos candentes que, inclusos ou latentes no leque ilimitado da realidade que se lhe apresentava, foram por si escolhidas e concentradas, até esse ponto, ígneo. E assim ainda, esta eleição e diferenciação efetuada levará por ela própria essa realidade a uma dada $c$ insuspeita estrutura - realidade que, para o comum dos mortais seus semelhantes e contemporâneos, se apresentava como dado informe, uniforme ou indiferenciado: só como mera possibilidade. Desde então nela criando uma grelha referenciadora e estruturadora, em linhas, pólos e coordenadas de força.

Assim, entre todo esse leque ilimitado de escolha que a realidade em si detém e apresenta há, por parte dum artista, um ato prévio de seleçāo como exclusāo, com algo de unívoco, ou destruidor e que será tanto maior quanto maior for esse artista.

A esse final ato de estruturaçāo - como vero ato de criaçāo, porque fazendo passar uma realidade, do indiferenciado como caos, à clara organização, como mundo - sob esse certo número limitado de verdades, e elas todas ainda por si, não mais do que diferentes modos ou aspectos duma só verdade, única, e delas a unificadora - se chamará uma cosmovisão.

Em Gil Vicente, essa cosmovisão se apresentará fortemente situada, no tempo e espaço, histórica e nacionalmente, por fundas raizes de vida, assim pulsando em uníssono com uma época e uma alma coletiva.

A época. é essa charneira, entre duas idades da história do Oci-

* A autora \& Bacharel em Ciencias Históricas e Fulosoficas pela Faculdade de Letras da Universidade de Coimbra (1944). Publicou Liexperience de l'extase (Enprit, no 11, nov. 1970) e, alnda, o Esoterismo de Fernando Pesson, $\Lambda$ força do mundo. Encontro na nolte, Duas epopélas das Américas, respeciivamente em 1971. 19721973 e 1974 no Porto onde reside. Em Arquivos (v. 2, ni 5) publicou $A$ multiplicidade dos mundos na poesia de Fernando Pegson. 
dente, ela como das mais dramáticas entre todas as suas, e a que Huizinga ${ }^{1}$ chamou de "Outono da Idade Média". A alma, é a lusíada, vinda e vinculada fortemente a essa época antecedente e ainda atual, que então se morria nesses justos anos.

E agora, nesta nossa atualidade, ela também como época de transição, tão semelhante a essa outra, em si vivendo e em si tendo de assumir a distensāo. propriamente insuportável, entre duas épocas, uma que se morre, outra que se anuncia nas dores dum parto de alumbramento mais ou menos demorado - todo o nosso gesto de homens atuais, de nos curvarmos sobre o testemunho de Gil Vicente, ultrapassará os limites puramente eruditos ou literários com que sua obra nos possa surgir, ou nela deter e conter. em primeira ou primária aparência ou aproximação. Mas antes, esse gesto, ele serả mais útil. se feito pelo, ou no. núcleo vivo. fremente e intocável, dum testemunho, o que na sua obra sempre perdurou e veio até nós e que. nele próprio, será sempre atual c utilizável.

Assim, tudo agora nele será para nós um testemunho para o passado, mas também para o presente. E assim, nada será como uma exumação dum morto, mas como uma comunhāo com um ressuscitado. Na sua vida eterna.

Porque essa sua cosmovisão, na sua estrutura própria, como toda vera criação. conceder-nos-á uma força ordenada e ordenadora, a um tempo dessa época e da nossa própria. E a um tempo nacional e universal.

Porque Gil Vicente, como grande poeta, mostrar-se-á tanto mais universal quanto mais forte, arraigada e especificamente nacional foi. viveu e criou - simultaneamente situado num tempo e num espaço e desse tempo e espaço independente. Pela sua realização eminentemente nacional e épocal, ao lado dela e justamente por ela, em dupla dimensão, estará detida uma outra, transhistórica e universal. Sua obra. de dramaturgo e poeta, reconstitui e transmite. viva, uma dada época, mas também terá força de, incessantemente, na sua potência infinita e multıdona, que é a da criação simbólica, influenciar, conduzindo e plasmando, outras épocas, sucessivas da humanidade.

Assim. uma tentativa de apreensão de certas verdades incluidas na obra vicentina, ou apreensão duma parte de sua temática, não se fará agora em moldes ou finalidade desinteressada: mas sim, visando uma utilidade: pragmaticamente se irá nesta nossa atualidade, pedir a sua obra que nos ajude a viver. Que. através duma temática, a um tempo e inseparavelmente, cognitiva e existencial, ela universal e eterna, mas plasmada em termos duma tradição nacional, um dramaturgo e poeta português do século XVI, torne mais conscientes e mais potentes os homens dos nossos dias, e, particularmente, ou eleitamente, os da comunidade de que ele fez parte e para a qual criou, a

l hurzinga. J. Le déclin du Moyen Age. Parls, Payot, 1948. 
resolverem seus problemas humanos, os mais prementes. Assim, em toda essa temática, tentaremos descer até ao seu fundo mais fundo e aí eleger algo dum denominador comum, que scrá como o seu centro imanizador de todos csses temas - c este talvez se possa ver como o problema da salvação; e se mostre, ou se demonstre por ele, como um diálogo vivido entre o homem e Dcus, por sucessivas e reciprocas perguntas e respostas - c cstas como de justificaçăo.

Assim, tripla e unidamente, se tentará captar algo, através da obra vicentina, do fundo da alma de scu criador, daquele da sua comunidade e daquele da sua época: por estratos ou transparências sucessivas. O que será, por uma dada manifestação de cultura, tentar chegar a uma das idéias mais fortes que criaram e plasmaram essa própria cultura nas suas múltiplas e diversas manifestaçōes.

Nessa criação vicentina, na sua complexa e altamente diferenciada estrutura, os enfoques possiveis, ou ainda, os planos possíveis sob que ela poderá ser tomada, ou lida, serão ilimitados. Haverá o testemunho do poeta áulico. como o porta-voz do soberano numa obra de alcance e limites políticos à medida da terra inteira, a que se manifesta no Auto da Fama, na Exortaçāo da Guerra; ou aquele do criador das tragicomédias, Cortes de Júpiter, D. Duardos, como anunciador da nova arte profana ao serviço duma corte, na sede duma sociedade por uma vida mais bela; ou o do porta-voz numa obra de doutrinação e didática religiosa, como a da roda da Rainha D. Leonor. Mas também a do poeta popular, onde, e por quem, se manifesta a sabedoria, as tradiçōes e os mitos duma alma arcaica vindo dos fundos do tempo; e por quem sc manifesta a voz consciente e explicita duma comunidade e nela, de cada um dos seus homens, na sua pessoa específica e irredutível, testemunhando scus mais fundos anseios espirituais, em esperança e angústia, nessas eternas perguntas do homem que, perplexa $c$ inelutavelmente, se situa entre cću $e$ inferno, ou beatitude $c$ danação. Como em situação limite, não permitindo subterfúgios, delongas ou desistências: assim cstará o homem de Gil Vicente. Em todo o seu poder de captar c por si viver os seus problemas derradeiros. Será esse que, mais potentemente, surgirá nos autos de Devoção. Nesse seu diálogo constante, em suspensão, com Deus. Direto. E sempre em aberto.

Assim, agora elcjamos só, entrc todos os múltiplos, possíveis e igualmente legítimos enfoques - um só fundamentalmente, ele como constituindo a orgânica do teatro de Gil Vicente - o problema da salvação do homem.

E tudo se procurará, ainda, fazer sempre nessa perspectiva e prospeç̧ão, por uma visão dupla, entre duas épocas. a de Gil Vicente e a nossa própria: para essa eficácia procurada; assim tudo se processando através dum elo comum entre ambas e procurando sempre uma forma de solução dessa problemática existencial - a que, mais do que em nenhuma outra época histórica se porá sempre em toda aque- 
la que se sente situada cntre um fim e um principio de ciclo da humanidade, tendo por si de sofrer a destruiçāo e morte duma tábua de valores, um conjunto vivo axiológico antecedente, dele se sentir abandonada - e abandoná-lo - e sobre elc, ou apesar dele, esperar um outro: numa criação que não seja feita de escombros.

Mas, entre toda a semelhança possível que agora possamos intuir entre as duas épocas históricas. esta da nossa atualidade e a desse fim da Idade Média, elas sendo justamente de cariz apocalíptico, algo haverá que nos obrigando a uma como culbutaçāo, mais do que revisāo total, de todos os nossos esquemas vividos ou visōes existenciais e cognitivas que informam nossa época histórica, justamente por si será de força e eficácia podcrosa (por esse choque): o sentimento irresistível do sagrado, patente e impregnante em todas as criaçōes dessa época histórica - e supremamente na obra vicentina.

Será esse sentimento quc, mais do que tudo, nos pedirá (para essa tal eficácia. de práxis) que, ao curvarmo-nos sobre cssa obra e época em que foi criada, não transportemos para ela nossos próprios esquemas ou perspectivas (ou ausência de esquemas ou perspectivas significativas, como por falta de referència transcendente.) Mas, cm humildade derradeira, por uma autentica conversāo. sem fazer tradução duma época numa outra. como na nossa própria língua, nos esforcemos de a ler no original, para que ela nos possa conceder todo seu pleno dom, o mais intacto possivel. Como gesto de nos curvarmos sobre uma fonte e nela, livres. beber a água da vida verdadeira.

Nessa obra, no seu sentimento do sagrado, haverá essa constante referência transcendente do homem ao divino, em ligação matricial. sempre a ele referindo c ligando sua vida e fim sobre esta terra. E que constituirá por si o sentido teleológico de toda a obra e mensagem de Gil Vicente. E nessa ligação, será o grande problema entre o homem e Deus. do Bem e do Mal, como sua salvação ou danaçāo, em enigma de soluçāo imprevisivel aos olhos terrestres, o que é debatido na Trilogia vicentina: e o mesmo que ainda, singularmente, se refletirá nos nossos dias. no Processo de Kafka.

Essa época, dramática entre todas as da humanidade, era a eleita para tomar esse problema e levá-lo até ao mais fundo das suas implicaçōes; e entāo, concretamente, ele tinha tomado nesses justos anos da criação da Trilogia. uma extrema acuidade. com a doutrina de Occam e a predestinaçāo. Gabriel Biel e os alemães nāo queriam impor a Deus a razão humana, mas salvaguardar a liberdade $c$ decisāo divina. E será ainda este mistério, como impossibilidade de prever c definir o bem c o mal no critério divino, o que ainda nos nossos dias fará todo o drama do romance de Kafka. O que se debate nesses anos. será a liberdade, a predestinaçāo e a justiça divina, mas dentro da esfera existencial dos homens, como problema seu, intensa e poderosamente vivido, como em teologia experimental. 
Parece que a soluçāo da liberdade, seria a solução fácil, perante a impossibilidade de estabelecer a ignorada escala de valores divinos. Ora, em Gil Vicente, através da Trilogia, este problema da salvação aparece apresentado numa resolução dinâmica, não estática, como processo em vias de sc fazer, ou meditar, duplamente, através de suas très cenas: por um movimento crescente que se vai fazendo, desde a Barca do Inferno, passando pela Barca do Purgatório, até que na última, na Barca da Gloria, terá cm si, por um movimento inesperado e fulgurante, sua solução gloriosa - na plena liberdade de Deus. co. mo Redentor.

Na Trilogia, perpassará assim, desde o seu começo até ao fim, um processo vivo, que a si mesmo se apresentará e solucionará, através de todas as possibilidades ou perplexidades que o homem se porá a si mesmo, ou a Deus, em última instância: nesse diálogo ou confrontaçāo mútua. entre um juízo humano e um juízo divino. E tudo no seu desfecho final, se soluciona por essa força redentora do amor, para além da justiça.

A esse movimento que anima pclo interior, intensa e secretamentc a Trilogia, como uma luz, desde o princípio somente como prometida ou suspeita, oculta nas tyevas e daí lentamente subindo, ou dealbando, cada vez mais aberta, até à plenitude da última cena, a da glória, se chamará, do lado divino, a graça. Do lado humano, no início, ela terá, polarmente, como trevas a si contrapostas, ou força de matéria ocultante e obstantc, o que se chama a soberba, a força da Queda, ou luciferiana. Como força de amor próprio, só sob o homem se fechando c concentrando; como egolatria, ausência de humildade e despojamento próprio, $\mathrm{cm}$ dom a outro, e que, da parte do homem. será o que impcde a ação sobre si. e sobre a terra, através de si dessa força purificadora c salvadora, descida do céu.

Os homens que entram na "barca perdida", na primeira cena, todos eles vêm e se apresentam ao arrais do céu, por demais sobrecarregados de suas pessoas; impediclos por pesos a mais próprios: pesos que eles, serāo apresentados, a um tempo em concreto e cm simbúlico. por objetos: a grande cadeira do Fidalgo, o bolsão do Onzeneiro, que tomará todo o navio, as formas que o Sapateiro carrega e que quererá pôr "bem chantadas/No cantinho desse leito". 2

Aspectos diversos dessa soberba que o rei filósofo D. Duarte tão intensamente tinha analisado: "Falando primciro da soberva que procede da presunçom e desejo de propria vantagem, em ella sam tres partes. Primeira, que pensamos que as cousas trouxemos, ou podemos trazer a algûa boa fim sem especial ajuda e a graça de nosso scnhor, pera bem de nossa alma, saude e boo proveito ou virtuoso prazer querendo semelhar a Lucifel que dissc: "Subirei e serei seme.

2 VICENTE, Gil. Obras completns. Lisboa, Sá da Costa, 1942. v. 2, p. 57. 
lhante ao muy alto", Leal Conselheiro, cap. x. 3 Nessa soberba se apresenta o Fidalgo ao Anjo: "Sou fidalgo de solar/He bem que me recolhais", 4 ou o Frade, que se diz "tanto dado à virtude", ou a Alcoviteira, que fez "obras mui divinas" 5 "Pois estou-vos allegando/O porque m'haveis de levar" 6

Mas ao contrário, só passará na barca do céu o Parvo; assim lhe anuncia o Anjo, "Porque em todos os teus fazeres per malicia não erras. te",7 que é propriamente o pecado contra o Espírito Santo, como ainda diz o Rei filósofo: "Em o padre pecamos per impotencia, em o filho per ignorancia, e em o espiritu sancto per certa mallicia. Esto he: quando a voontade pode e sabe contradizer algủu mal, e empero per so mallicia aquello scolhe", 8

Unico, a todos esses homens oposto, surgirá o Parvo, no despojamento total de si próprio que, à pergunta do arrais do Inferno. "Quem he tu?", 9 a si se apresenta pela simples impossibilidade de adjetivação. na sua pura essência, "cu soo". Assim, pela sua humildade. parafraseando ou imitando a mais subida glória na essência do ser, a do próprio Deus, que a Moisés, no alto do Monte Horeb, na sua epifania, se define a si mesmo como. "Eu sou aquele que sou". 10

E ainda depois. quando o arrais do céu lhe pergunta de novo. "Quem es tu?" ele levará, acaso mais longe um despojamento dum ser, porque até ao seu não-ser, como ápice, sublimação derradeira, pela sua própria negaçāo. "Não sou ninguém". 11

E entāo. será ele o único a salvar-se, a merecer do Anjo a entrada na sua barca, a barca do céu: ele, e os Cavalciros da Ordem de Cristo, que "morrerāo nas partes de Africa", 12 "Santos por certo sem falha".13 Eles também como os que cm si próprios, para um serviço pátrio de sentido tclcológico. perfizeram esse despojamento total. como dom da ressoa, para outro que a ultrapassa. O Parvo e os Quatro Cavaleiros de Cristo, em si representarão, e em linguagem nacional, o Sacrifício. como oferta do homem a Deus, oblaçāo, na identificação com Ele como a mais perfeita forma de divinizaçāo.

Nesta primeira cena da Trilogia, tudo se passa entre diabos, homens e o anjo. Diabos, três, e um só anjo, o arrais do céu. Mas na segunda ccna, a atribuida à Embarcaçāo do Purgatório, os anjos au-

3 DUARTE, rei de Portugal. Ieal Conselhelro. cap. $X$.

4 VICENTE, $D .44$

5 Ibid., p. 59.

6 Ibld., ?. 65.

7 Ibid., p. 67 .

8 DUARTE, can. LXIII.

9 Ibld.. p. 54

10 Exodo. In: BIBlia Sagrada, Sảo Paulo, Fd. das Américas, 1950. v, I p. 226 .

11 VICENTE, n. 54.

12 Ibid., p. 81 .

13 Ibld. . p. 82 . 
mentam em número: e com eles, a alegria; há o arrais do céu e ainda os três remadores que, logo no começo, quando a cena se abre, surgem cantando o Romance da esperança, de tão doce embalo.

"Remando vão remadores / barca de grande alegria; / o patrāo que a guiava, / Filho de Deus se dizia. / Anjos erăo os remeiros, / Que remavão á porfia"; 14

Como anúncio que tudo então seria diferente. Como também o mar transcendente, ou da surnatureza, em si já mostrava: do lado da barca do céu, "A ribeira mui serena / Que nenhum vento bolia". ${ }^{15}$

$E$ do lado da barca do inferno, o scu arrais se lamentará: " $E$ que he isto na ma ora? / e o batel está em secco' / Oh renego de Çamo$\mathrm{ra}^{\prime} / \mathrm{O}$ rio se encaramelou' / Nunca tal m'aconteceo". ${ }^{16}$ Ele, que na cena antecedente tinha exclamado, convidando os homens: "A barca, á barca. senhores' / Oh que maré tão de prata' / Hum ventosinho que mata". 17

Mas agora, nesse mar transcendente. outra força estará agindo, opondo-se à do mal.

E os homens, poderāo ainda vir, comı na primeira cenal. carregados de suas soberbas, tal o Lavrador com seu arado is costas.

"Diabo: - "Pois porque vens carregado? / Lavrador: - Porque seja conrecido / Por lavrador muito honrado / E tenho a gloria merecido; / Que sempre fui perseguido. / E vivi mui trabalhado" $18 \mathrm{E}$ a mesma justiça do Anjo se pesar ainda pelas obras feitas sobre a tcrra. em toda a sua irreversibilidade: "Que bens fizeste na vida / Que te sejão ca guiantes?" 19, como ele pregunta. Mas a Regateira Marta Gil. já sabe que "Este serão glorioso / Não he de justiça, não; / Mas todo mui piedoso, / Em que nasceu o esposo / Da humanal geração: / E a barca de Satão / Não passa hoje ninguem;" 20

Porque a cena ocorre nas matinas do Natal. E a primeira fala do arrais do Céu aos homens, e já de apelo e confiança, em pura alegria: "Quem quer ir ó Paraiso? / A glória, á glória, senhores! / Oh que noite pera isso?" 21

E então, ć como se tudo começasse a abrir-sc, ou iluminar-se, em jubilação, por uma força nova, de luz, num movimento crescente e incontido. Como uma saída da noite para o dia, ou das trevas da ignorância para a claridade do conhecimento: Aviae-vos, e partir; / Quc vossa vida he sonhar, / E a morte he despertar / Pera nunca mais dormir, / Nem acordar. 22

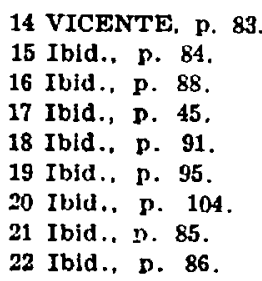


E essa força iluminante $\dot{c}$ a graça. E o principio da cena se realiza e se afirma logo, dialeticamente, entre o convite do Diabo. Arrais do Inferno e o convite do Anjo. Arrais do céu. como força de pecado e força da graça. "A terra, á terra. mortaes' / Cerrar o leme, a esta banda, / e não curar d'outro cais; / porque a lei dos mundanaes / isto manda". 23

Mas a esta força humana de pecado. como Lei. se contrapōe uma outra, celeste, como graça, proclamada pelo Anjo: " $E$ o batel dos danados / Porque naceo hoje Christo / Esta c'os remos quebrados / Em seco. O descuidados / Cuidae nisto". $24 \mathrm{E}$ a Redenção virá como sempre na obra de Gil Vicente, unida à intercepçāo da Vírgem. a "prol de toda a perfeição", 25 prol de toda llas mulheres".26 Assim recomenda o Anjo aos homens: "Pedi-lhe como avogada / Per lacrimosa linguagem, / Que nos procure viagem / Descansada". 27

E do poder dessa força, sabe-o também o Pastor, que com sua fé, respondc ao Diabo: "Nāo podes nada fazer / Na noite que quiz nacer Christo filho de David". 28 E a Moça implora, "Oh'chagas de Jesu Christo / Vão em minha companhia'" 29

E desde então, à danação eterna, se substituirá o tempo intermediário, do purgatório. "Purga ao longo da ribeira / segura da danação / terás angústia e paixão i e tormento en gran maneira / Isto até que o Senhor queira / Que te passemos o rio": assim diz o Anjo a Marta Gil. 30

A fé dos homens na obra redentora do amor de Deus cresce e se afirma nesta segunda cena. E, exceto o Taful, culpado de "Renegar tão feramente / da Imperatriz dos Coos" 31, todos ficam purgando ao longo da ribeira. E para o céu, leva o Anjo no seu batel o Menino de tenra idade. a quem Deus fez "secretamente / a mais profunda mercè". 32

Na terceira e última cena, endereçada à Embarcaçāo da Glória, os anjos aumentam ainda em número. Na cena anterior, "Primeiramente entrão très Anjos, cantando o romance..." 33 Mas agora, nesta cena, "Primeiramente, entrão quatro anjos cantando, e trazem cinco remos

23 VICENTE, p. 85.

24 Ibld., p. 86.

25 Ibid.. p. 87.

26 Ibld.. p. 87.

27 Ibld.. p. 87.

28 Ibld.. p. 109.

29 Ibld.. p. 113.

30 Ibld.. p. 105.

31 Ibid., p. 122.

32 Ibid.. ว. 121.

33 Ibld.. n. 83. 
com as cinco chagas..." $34 \mathrm{E}$ a luz e a alegria ainda aumentam, e de todo se revelam.

E o drama do homem atingirá, por concentração derradeira, o seu clímax. E cssa concentração se fará toda por contraste, por junção da força da sua misćria, pela Queda, e da força da sua glória, pela Redenção.

Esta cena é das três a que em si transporta uma carga mais agudamente dramática, porque feita por esses extremos e sem cessar indo dum a outro, como das trevas à luz resplandecente, ou da dor do homem ao amor de Deus.

E assim também por ela, a que em si transporta mais fundamente a marca da sua época: entre o fim da Idade Média e Renascença, ela toda, feita por contrastes. Em toda a sua concepção realista e algo materialista da morte, no seu horror à corrupção do corpo, à brevidade da vida sobre a terra, e perante a qual todos os homens socialmente desiguais serão igualados. cla se apresentará como uma Dança da Morte. Como novidade na Trilogia, surgirá a figura da Morte, tomando doravante parte no diálogo entre os homens, diabos e anjos. E que ela. por si, dará e marcará, do lado humano, toda a medida trágica da vida, em acuidade derradeira, a um tempo cruel e cheia de piedade: como vida vivida após a Queda, sujeita à degradaçāo e perda do corpo terrestre, ao sofrimento, distanciaçāo de Deus, e fugacidade do tempo na sua medida inexorável, como passagem irreversivel de sucessivos instantes presentes.

O Diabo e a Morte representarão, opostamente a esperança e a fé expressada pelos homens - aqui, como em nenhuma das outras duas cenas anteriores, em tal força desabrochada, de Mal e Bem. a dor e a miséria desta vida terrestre, ela toda, suspensa na obra de redenção de Cristo. Dir-se-ia que Gil Vicente, para fazer ressaltar mais vivamente a glória concedida aos homens, mostra-nos como nunca, na sua dor, em toda a infinita profundeza. Em nenhuma das outras cenas, a vida terrestre e condição humana sujeita ao diabo, à morte e ao tempo, desce a tal abismo da terra, em escuridão. para no fim. bruscamente, subir a tal cume do céu em luz resplandccentc. E é dessa escuridão de abismo do início, que, logo como anúncio de tudo. se eleva a breve e aguda prece do Anjo, como jaculatória, que irá furar o céu. " $O$ Vírgem nucstra Senöra, / sed vos su socorredora/en la hora de la muerte". 35

Nesse justo momento do começo, todos os homens ("Trata-se por dignidades altas") sairam do mundo, abandonando seu corpo de car. ne que a morte atormentou e desfez. "O Muerte'cuan trabajado/salgo triste de tu mano' [...] Como quedas, cuerpo triste?/Dame nuevas,

34 VICENTE, p. 125.

35 Ibld., 3. 128.

36 Ibld., p. 129 . 
que es de ti. /Siempre en guerra me troxiste /Con dolor me despediste, /sin haber dolor de mi", 37 pergunta o Duque.

Como nunca, o diabo foi tăo perverso na sua acolhida aos homens para a fatal viagem. "y partamos con de dia: /Cantaremos a porfia/"Los hijos de Dona Sancha". 38 E como nunca referida assim toda a miséria c abandono dos homens" decidme, Senōr, porqué/Tan presto me derrocaste/De cabeza?/Rue 39 gote que no escaeza/Quod stcut lutum me reciste/No permitas que perezca"; numa tal uniāo de dor e esperança.

E como nunca também. dada a descrição concreta e realisticamente alucinatória do Inferno: nas cenas anteriores, ele se tinha apresentado tão somente como "n'a Ilha perdida, "a infernal comarca", "a terra dos damnados". Mas agora o diabo aponta-a a cada homem dai, de longe e perto, em todo o antegozo de seus diversificados tormentos, cruelmente, um a um; numa descriçāo que por ela marcará toda uma geografia transcendente do pavor. "Veis aquel gran fumo cspeso, /que sale daqellas peñas? /Alli perdereis el vueso, /y mas, Señor, os confieso/Que habcis de mensar las greñas" 40; mostra o diabo ao Conde. Ou ao Duque: "Veis aquella puente ardiendo, /muy lejos allen del mar, /y uns ruedas volviendo/e navajas, y herindo? Pues alli habeis de andar/Siempre jamas". 41 Porque tudo se faz, nesses tormentos, na medida sem medida da eternidade, sem fim.

Assim, ele os continua mostrando agora ao Papa: "Veis aquelos azotor/Con vergas de hierro ardiendo, / $\mathrm{Y}$ des pues atanazar? pues alli habeis de andar/Para siempre padeciendo". 42 E sempre em variedade crescente, ele as vai apontando. Ao Bispo: "De ahi donde estais vereis/unas calderas de pez,/Adonde os cocereis/y la corona asareis", 43 Ou ao Arcebispo: "Vucstra Señoria irá/En cien mil pedazos hecho/y para siempre estará /en agua que herverá, /Y nunca sereis deshecho". 44 E este pavor será complctado, perfeito, através de todos os sentidos do outro mundo e corpo, transfísicos, numa acuidade de ver c ouvir que implacavelmente reforçarão esse cerco do pavor, por um realismo mágico, de pesadelo. Assim o diabo convida o "Domine Cardinalis" a ouvir atentamente "Oyes aquel gran ruido/ $\mathrm{Nel}$ lago de los leones?/Despertad bien el oido: / Vos sereis alli comido/De canes y de dragones".

Mas sempre em tudo, através destas très cenas sucessivas da Tri-

37 VICENTE, p. 134.

38 Ibld.. p. 179.

39 Ibid... p. 135.

40 Ibid.. p. 130.

41 Ibld.. p. 135.

42 Ibid., p. 164.

43 Ibid., 5. $1 \leq 9$.

44 Ibid.. s. 155 . 
logia, à força em aumento do mal, como tormento de pecado atual sofrido e lembrado e tormento de castigo futuro mostrado pelo diabo, - que nunca como aqui foi tão aliciante e melífluo no seu prazer de torturar - uma outra força, em aumento também, se lhe contraporá da parte dos homens: a sua fé e esperança na obra redentora de Cristo $c$ intercessora da Virgem. Entretecidamente, a essas visões de tormento dadas pelo diabo, os homens contrapõem as preces da sua fé. E o Anjo, suas jacultórias. "Plega á vuestro Redentor,/Nuestro Dlos y creador, /que os dé segundas vidas". 45

O Imperador dirá seu Responso: "O libera me, Domine,/de muerte, eterna contienda: /en ti siempre tuve fé",46 Ou o Bispo: "Responde mihl cutantes son /mis maldades y pecados/veremos si tu passion/ bastara á mi redencion/aun que mil veces doblados". 47

Este movimento como pendular, fortemente oposto, constante e unido, de pecado e esperança, ou condenação e salvação, como Queda e força das três virtudes teologais, e no fim o declarar e rebentar derradeiro da força da Redenção, na vinda, apariçāo brusca de Cristo, o que formará a dinâmica propulsora da última cena da Trilogia - $\mathrm{e}$ marcará sua mensagem suprema, em desfecho.

O Bcm, a salvação. se elevará, nascerá e se formará, necessariamente do Mal, da perdição. A justificação do Mal neste mundo está no Bem que ele servc, como negro solo necessário de podridão donde necessariamente nascerá e se elevará sua alva flor.

Maior que a força de pecado do homem, será a força de misericórdia de Deus. Por isso, a melodia em contraponto que constantemente se vai desenvolvendo através da Barca da Glória, será marcada pelos pecados dos homens apresentados pelo diabo no seu castigo infernal, pela miséria e fraqueza expressada nas Liçōes pelos homens e por eles assumidas em humildade c pela sua fé expressada nos Responsos. A todas as culpas, apresentadas implacavelmente uma a uma pelo diabo aos grandes da terra, não haverá, tal como na primeira cena da Trilogia, a contraposiçāo de sua justificação pelas obras e méritos próprios, na soberba; mas agora, tão somente, na humildade, a apresentaçāo por cada um, da grandeza do homem, porque criado pclas mãos de Deus, da sua queda e fraqueza quando sem sua ajuda e sua firme esperança na obra redentora da Paixão e da "Reina celestial, Abogada general".

Desde o começo da cena, haverá essa força de fé dos homens, no seu amor, que cada vez mais poderosamente se vai elevando de seus coraçōes, nes suas vozes, até que no fim, no justo momento da verdade, tcrá do lado de Deus, a responder-lhe ou corresponder-lhe, o gesto súbito na sua apariçăo como Redentor concedendo-lhe a salva-

46 VICENTE, p. 160 .

46 Ibid.. D. 142.

47 Ibid., p. 146 . 
ção, cm pura gratuidade: no justo momento do fim, já depois que o Anjo desfere a vela da sua barca e vai partir sem consigo levar os homens, a si suplicantes, e que à sua roda fazem coro, juntando suas oraçōes ao Pastor crucificado:

- Cordeiro divinal/médico !do nuestro daño/ Viva fuente perenal,/ nuesa carne natural;/ no permitas tanto daño,/48

e "veio Christo da ressurreiçāo, e repartio por elles os remos das chagas e os levou comsigo". 49

A época de Gil Vicente é a época da graça. E ela a preocupaçāo grande dos homens, não somente no distante campo da teologia dogmática ou abstrata, mas como em tcologia experimental. Porque tudo então foi sentido, não somente no intelecto, mas na alma, como problema vivido, em dado limite da vida. Vivido, por um homem integral, existencialmente.

Assim também surgirá a graça na obra de Gil Vicente. Como em reflexo da sua alma pessoal e daqucla da sua época.

O poeta se confessará no Sermão "feito à cristianissima Rainha D. I.conor e pregado em Abrantes", em 1506: "esteril de sciencia, de graça ambriento". E esse Sermão tendo um cunho personalíssimo, se mostrará com todo o alcance dum auto-espiritual. Nele havendo, por parte do poeta, toda uma posição assumida, revelando um caráter c uma via de vida e conhecimento, realizando-se e desenvolvendo-se preferentemente pela esfera do sentimento e da intuição, mais que pela da razāo e do discurso. E tudo Ievará a crer, por esparsas confissōes que surgem de cariz pessoal através da obra do dramaturgo e poeta, que o seu pensamento era de tendéncia mistica c portanto cm si contendo uma forte predominância de elementos irracionais: 0 que desde logo justificará a valorizaçāo na sua obra, da predestinação e da graça, que elas, pertencerão ao campo do irracional. Talvez tendência mística dum pensamento, mas por certo, em si contendo a marca específica da alma nacional, como forte sentido de realismo positivo, concreto, ou sempre em equilíbrio estável entre o céu e a terra. Ainda no mesmo Sermão. o poeta especificará mais essa sua posição. "No quiero tocar secretos guardados,/No quiero meterme en divinas honduras, $\mathrm{Ni}$ quiero volar naquellas alturas/Do quemam las alas dos desassesados/No quiero ser uno de algunos letrados,/Que por demonstrarse profundos varones Disputam consigo en lar predicaciones/Y en las escuclas, estanse calados". Dirá assim sua atitude, longe de todo $o$ interesse, a um tempo pela mística especulativa, ou pela teologia e pelas questōes dum saber nāo aplicado ou não existencial, secamente erudito de escolástica, ou humanismo.

48 VICENTE, p. 150 .

49 Ibid., D. 168.

50 Ibid., p. 169. 
$\mathrm{Na}$ simples e humilde fé dum contemplativo, se apresentará o poeta no Auto Pastoril Castelhano, pela voz do pastor Gil, em oposição a scu companheiro Brás, ele todo dado à açāo. "Solo quiero canticar,/Repartando mis cabritas/Por estas sierras benditas:/No me acuerdo del lugar,/Cuando, cara al cielo, oteo,/Y veo tan buena cosa".

Mas na Trilogia, obra sem marca confessional tão pessoal e direta, a graça, mostrando-se e agindo como força interna dinamizadora e justificadora, se perguntará: teria havido nela o intuito de denunciar o erro daqueles que põem toda a sua confiança nas obras? Como parte unicamente humana na economia da salvaçāo? E nela, poder-se-á considerar Gil Vicente como o arauto duma atitude doutrinária da graça, confirmada na sua última cena, e seu próprio desfecho, a Barca da Glória? Ver-se, na Trilogia, no seu movimento de vida, vindo e desenvolvendo-se, desde o princípio até a sua plenitude, desde a Barca do Inferno, passando pela Barca do Purgatório, até a Barca da Glória, como um caminhar progressivo para a declaraçāo e efetivação dessa força transcendente salvadora?

Mas, afigura-se legítimo ainda, através da obra vicentina, ultrapassando os limites duma confissāo ou posiçāo assumida, que ela não poderia ser de caráter c limites estritamente pessoais, - e aqui mormente na Trilogia, difícil de aceitar, dado o lugar responsável e eminente que o poeta ocupava na corte e portanto no reino, como uma das suas vozes cxplícitas mais acatadas - ver antes essa confissão ou posiçāo, mais latamente como a expressão consciente e voluntária inserida numa obra didática, a um tempo de ideal $e$ ação, teoria e prática, como a levada a cabo pela Rainha $D$. Leonor. Ação duma elite, no seio duma comunidade nacional. Surgindo assim Gil Vicente, como o poeta áulico, fazendo parte da roda da Rainha Velha, em lugar similar ao do impressor Valentim Fernandes, escudeiro de sua casa e serviço, por quem foi incumbido do alto cargo de "estāpar e de forma fazer em lingoa materua e portugues linguagem: como de feito com divino favor per obra comprio: com muita despeza da sua fazenda": como ele próprio dirá na epistola que antecede a Vita Christi. Através da arte que então surgia, a imprensa, pela traduçāo do latim, e sua propagação em língua vulgar, dos escritos religiosos, c da arte eminentemente social do teatro, D. Leonor levava a cabo essa obra de esclarecimento religioso, como uma cruzada; e ela ainda completada pela obra da Miscricórdia entre os homens. E assim, a criaçāo do dramaturgo, nos surge vinculada a um sentido que ultrapassa os limites e alcance duma mera expressāo de caráter pessoal, como o dum pensador e poeta que seria independente e único na sua criação individual, - para atingir aqueles duma obra didática, doutrinária e de caridade, como aqueia a que presidia alta e esclarecida. mente a Rainha.

E por agora, não ousando, em tão curtas páginas desenvolver nem justificar esse delicado problema da aproximação - para uma opo- 
sição ou identidade - da obra vicentina com todos os movimentos contemporâneos, heterodoxos ou ortodoxos, poder-se-á dizer que haverá através da Trilogia, o desenvolvimento explícito duma fé mistica da graça, que ela, se irá acentuando e terá sua plenitude na última cena; e que será, por um lado, como a expressāo simultânea do que na Europa de então teve manifestação em escritos da Pré-reforma, como o Diálogo da Doutrina Cristā, de Juan de Valdès, ou o tratado De L1. bertate Christiana, de Jean de Goch; e por outro, como a manifestação, em continuidade nacional, das fundas estimativas medievais formadoras e condutoras da nossa vida e espiritualidade religiosa. Pois em toda essa Trilogia, perpassarāo as crenças as mais específicas desses séculos anteriores da alma portuguesa: a funda e sentida devoção à Virgem c toda a sua obra intercessora, ela sempre unida à obra redentora de Cristo; e esta ainda, através de todo o culto da Paixão, revelando a influência franciscana, como das mais marcadas, a um tempo nesta nação, na própria corte e $D$. Leonor, c na própria alma de Gil Vicente.

As raizes doutrinárias e axiológicas da obra vicentina, se afundarão sempre no húmus da terra portuguesa e nesta, na idade quc então se morria, a Idade Média; mas, simultaneamente, elas serāo tocadas, ou vibradas, pelas fortes correntes que perpassavam na Europa desse tempo: sequer, para só levar o seu criador a tomar uma posição em face delas.

Essa obra expressará a fé em Dcus e na sua ação redentora de miscricórdia, e ela será similar à que podemos ver expressada $\mathrm{cm}$ contemporâneos, como a duma religião toda ela suspensa na graça e implicando uma justificação pela fé, mas que ela, não excluía, a parte de colaboraçāo humana; $\mathrm{e}$ ainda, não apresentada polêmica e heterodoxamente, como o foi por Lutero e luteranos; mas sim, dentro de toda a posição de ortodoxia católica, e longe daquela de controvérsia doutrinária. Valdès dirá "Não há um só justo, um único". O justo é o pecador justificado pela misericórdia divina, na sua própria fé. A mesma justificação, estará ainda expressada pelas palavras de Goch, "E unicamente a graça de Deus que atribui o mérito ao homem". $E$. aqui ainda esta posição se virá ligar, ou encontrar, com a corrente tradicional do pensamento português da Idade Média, a augustianismo. Ele também tão visivel em todo o pensamento vicentino. Lembremos só, que é S. Agostinho o intelecutor no Auto da Alma, uma das obras suas de mais fundo e vibrante sentido sagrado.

Augustianismo, expressado com suas raizes de paulinismo, o vemos já no Leal Conselheiro, quando D. Duarte se refere à soberba de Lucifer: " $E$ aqueste soo pensamento se afirma seer aazo de sua queda. E nosso senhor em contra deste disse que sem o pade cousa nom poderia fazer. E o apostollo: "Nom somos soficiente cuydar alguia cousa de nos, assy como de nos, mes nossa soficiencia de deos he (cap. $\mathrm{X}$ ). 
E será essa fé, expressada na Trilogia, aquela que nesse tempo se designava por fides charitale formata: a fé formada de caridade. Forma ortodoxa de estabelecer uma relação entre a fé e a caridade; a que posteriormente Lutero dará uma interpretação diversa e em controvérsia. Mas para Valdès, ela será a fonte das obras meritórias e tudo estará ainda longe do sentimento dos luteranos, dum homem esmagado pelo pecado, que mesmo quando recebe a graça divina, continua miserável e sem mérito. Longe ainda desse sentimento do pecado vencedor, num gênero humano corrompido e impotente. Assim, na obra de Gil Vicente, e neste ponto justamente central e atual da justificaçāo pela fé, não haverá nenhum reflexo de qualquer ideal lutcrans, mas somente a continuação, em sobrevivência, duma concepçāo católica de funda estimativa nacional, vinda da Idade Média; c assim, a afinidade no ideal dos pré-reformados dessa época.

Nestes anos em que se situa a criaçāo da Trilogia, serão imposstveis, ou de todo injustificados, quaisquer juízos ou classificaçōes doutrinárias no campo religioso, de caráter estrito ou univoco: tudo estava em mutação, nada era homogêneo e tudo sofria fundas contradições. E será só sob este ponto de vista que se poderá tentar uma aproximação e meditação de qualquer obra em si contendo um caráter teológico bem marcado, tal a de Gil Vicente.

Assim antes, através desta obra vicentina se tentou somente oscultar, como em repercussão, ou vibração, e ainda está em tom nacional, uma harmônica das ondas espirituais que então perpassavam na Europa dessa época, ela justamente sofrendo uma das suas mais dramáticas mutaçōes.

Fundamente integrada nela, como organismo humano e cultural, esteve mais do que nunca Portugal nessa época. Como coração, centro de toda a sua vida cspiritual e material, nenhum movimento, pulsão desse grande organismo, lhe era estranho, ou sequer sentido como longínguo; ou anacronicamente, como em séculos posteriores por vezes, se teria dado, e em tão funestas conseqüuencias. $E$ assim, nestas breves páginas, se teria tão somente pretendido vislumbrar na obra vicentina um ponto de meditação comum sobrc uma problema candente duma época, em perfeita sincronia.

E assim, acaso ainda para uma mais concreta aproximação, atentemos em algumas datas que, por elas, marcarăo como os níveis mais altos atingidos por essas ondas espirituais que entāo percorriam a Europa; e em máxima violência; e sua perfeita repercussāo entre nós numa mesma atualidade, como as próprias datas da criaçāo da Trilogia talvez nos possam mostrar. Assim: desde 1518, os escritos de Lutero circulavam em Antuérpia, cidade que era um dos mais importantes centros da representação de Portugal na Europa e de sua inserção nela, em toda a sua cultura; e ai, eles eram muito lidos e comentados pelos feitores portugueses. Segundo Aleandro, era Antuérpia, um dos centros mais em vista nessa época, de discusão dos 
prós e contras sobre esses escritos; e daí eles eram espalhados e divulgados por toda a Europa, no que colaboravam os judeus idos daqui da Península. E nessa cidade flamenga, cles seriam queimados cm 1519. E lembremos as datas da criação das três cenas da Trilogia. respectivamente, 1517,1518 e 1519 , assim contemporâneas de todo esse surto de protestantismo, que ele se faria justamente como revisão e mutação de todo o problema central que percorre as três cenas: as obras e a graça. Porque, tudio no pensamento do reformado alemão teria começado com a explicação da Epistola aos Romanos, que é de 1515/1516, quando cle já se sentia apoiado na doutrina da justificação pela fé.

E nesta sincronia, a temática comum e toda a sua dramatização, em fundas implicaçōes doutrinárias, que surge na Trilogia vicentina, deveria tomar acuidade e responsabilidade extrema, tanto para seu criador, como para seus contemporàneos espectadores. $E$ nada poderia assumir, caráter unicamente individual.

E essa meditação explicita sobre uma temática que então foi assumida existencialmente, nos demonstrará, ainda agora, os rumos do pensamento português dessa época, nas suas estimativas e opções as mais fundas, como de tendência ortodoxa, católica, longe de todos os exageros e extremismos contemporâneos, como os seguidos pelos luteranos. Sempre dentro da corrente da tradição, vinda da idade precedente, a que depunha no homem toda a responsabilidade, deixando-o só com sua fé na misericórdia de Deus; e será essa atitude, a um tempo de liberdade e de abandono derradeiro, a que percorre a $\mathrm{Tr}$. logia, e se declarará em plenitude na sua última cena: e que por ela, lhe dará toda a sua grandeza.

A relação funda, direta e pessoal, entre o homem e Deus, estará a frente de todos os interesses dos espíritos dessa época que, dadas as suas opçōes mais fundas, se colocam fora da corrente propriamente humanista, cla de teor antropocêntrico, e que irá moldar e conduzir posteriormente toda a cultural da Idade Moderna ocidental. Para esses espíritos, haverá como uma saturaçāo de toda a existência pela religião, esta tomada no seu vero sentido, como ligação entre o homem c Deus. E é ainda dentro desta perspectiva, ou estimativa, ela de tcor teocêntrico, que se coloca Gil Vicente e a obra criada por ele. E todos os temas ou perguntas que nela surgem, como soberania absoluta da graça divina, recusa de toda a teologia natural, idéia da penitência e ainda, antilegalismo, sāo os mesmos que ocuparam reformadores e luteranos. embora as interpretaçōes ou rumos elegidos, a partir deles, fossem de todo diversos. Uma mesma situaçāo do homem, haverá partilhada, toda ela oposta à dessa nova corrente humanista que entāo percorira a Europa; mas antes, em si continuando e representando a espiritualidade vinda da Idade Média. 


\section{REFFRENCIAS BIBLIOGRAFICAS}

Biblia Sagrada. Såo Paulo, Ed. das Américas, 1050. v. 1. Dunate, rel de Portugal. Leal Conselheiro.

Huizinga, J. Le déclin dn Moyen Age. Parls, Payot, 1948.

vicente, Gil. Obras completas. Lìbon. Sa da Costa, 1942, v. 2.

\section{Resumo}

Gil Vicente viveu numa época de transição, na ćpoca que Huizinga chamou de "outono da Idade Média". Vivendo na confluência de duas épocas, a cosmovisão de Gil Vicente reflete cssa ćpoca de transição e a alma lusitana, sem deixar de ser por isso universal porque a história se repete no tempo e no espaço. Vivemos hoje também uma Época de transição. Uma ćpoca em que uma escala de valores fixa e estabelecida está sendo rediscutida e parcialmente substituida.

No centro da problemática da Trilogia de Gil Vicente estāo os eternos problemas da liberdade humana, do Bem e do Mal e da salvação humana: se a salvação do homem é conseqüência mais da sua fé ou das suas obras, da graça ou do seu esforço, o que nos leva também ao problema da predestinação e à pergunta sobre a finalidade do homem nesta terra, se é mais importante ser ou ter. Na Barca do Céu só entram aqueles que se despojaram de si mesmos e náo têm apego aos bens terrenos.

O homem pecou, mas foi redimido. A Queda se sucede a Salvação, a Redenção pelo sofrimento de Cristo, onde também é ressaltado o papel de intercessão da Virgem, de grande devoção em Portugal. Maior que a força de pecado do homem. será a força de misericórdia de Deus. Essa obra expressará a fé em Deus e na sua obra redentora de misericórdia. e ela será similar à que podemos ver expressada em contemporâneos, como a duma religião toda ela suspensa na groça e implicando uma justificação pela fé, mas que ela não excluía a parte de colaboração humana.

Serão mera coincidência as datas de publicação da Trilogia (1517, 1518 e 1519) e a da circulação na Europa dos escritos de Lutero, em que se debatiam todos esses problemas? Provavelmente não, e a obra de Gil Vicente tem até uma função didática, como porta-voz da posição oficial da Corte.

\section{Summary}

Gil Vicente lived in a time of transition, a time that Huizinga called "the autumn of the Middle Ages". Living at the confluence of two ages, the weltanschauung" of Gil Vicente reflects this time of transition and the Lusitanian soul, being notwithstanding universal, because history repeats itself in time and space. Today we also live in a time of transition. A time in which a fixed and established scale of values is being reexamined and parcially substituted.

At the core of Gil Vicente's Trilogy are the eternal questions 
about human liberty, about Good and Evil, and about human salvation: if human salvation is a consequence more of ane's faith than of one's works, more of grace than of onc's endeavour. This arises also the problem of predestination, about the purpose of man on earth, if is is more important to be or to own. In the Boat of Heaven enter only thouse who are free from egoism and are not bound to earthly goods.

The man has transgressed the divine law, but was redeemed. After the Fall came the Salvation. the Redemption through Jesus Christ's suffering. In the fact of human redemption Gil Vicente cmphasizes the role of the Virgin, whose cult is very common in Portugal. Greater, however, than the human being's power to sin, is the power of God's mercy. The Trilogy expresses the faith in God and in his mercy, and it is similar to the one expressed in the works of contemporary authors. This religion is based on the grace and implies a justification by the faith but does not exclude the human colaboration.

It is a mere coincidence that the dates of the publication of the Trilogy of Gil Vicente $(1517,1518,1519)$ and those of the circulation in Europe of the writings of Luther were the same? It is probably not so, and Gil Vicente's works have even a didactit purpose, they were probably the official voice of the Court. 